\title{
INVESTIGATING THE IMPORTANCE OF CUSTOMER LIFETIME VALUE IN MODERN MARKETING - A LITERATURE REVIEW
}

\author{
Adela-Laura POPA ${ }^{1}$, Dinu Vlad SASU1, Teodora Mihaela TARCZA ${ }^{1}$, \\ ${ }^{1}$ Department of Management Marketing, Faculty of Economic Sciences, University \\ of Oradea, Oradea, Romania \\ apopa@uoradea.ro \\ dinusasu@gmail.com \\ teodoratarcza@gmail.com
}

\begin{abstract}
In this paper, we investigate the importance of Customer Lifetime Value $(C L V)$ as part of the modern marketing strategy. There is no doubt that CLV is one of the most important metrics to be considered in Customer Relationship Management and Relationship Marketing. It represents an instrument meant to enhance the client's loyalty and to bring some clearance for the marketing strategies regarding the customer segmentation. At the same time, it is one of the most difficult to calculate. As part of this study, we explore how the concept is approached in the academic literature, the notoriety of the concept, the areas, and the topics with which it is associated. In this investigation, we are using WordStat and QDA Miner software applications for content analysis and text mining aiming to extract themes and trends regarding the approached topic from a significant number of academic articles.
\end{abstract}

Keywords: Customer Lifetime Value; CLV; Customer Relationship Management; CRM; valuable customers; content analysis.

JEL Classification: M31

\section{Introduction. Context. Importance. Vision}

Customers are the lifeblood (Gupta and Zeithaml, 2006), the alma mater (EstrellaRamón et al., 2013) of any organization. There are many other ways to highlight the essence of what customers represent for any organization.

Modern marketing starts from premises like the importance of customers as the most valuable assets the companies own (Mosaddegh et al., 2021), customer centricity, the fact that different customers deserve different treatment, and not all customers are the same value (Gupta and Zeithaml, 2006; Estrella-Ramón et al., 2013). Customer metrics and greater measurability are also prerequisites without which modern marketing could not exist. Due to the many ways in which customer value could be understood and analyzed, estimating customer lifetime value is one of the most challenging metrics marketers are facing.

When approaching the concept of valuable customers, specialists often refer to the 80/20 rule (Pareto Principle) for highlighting the importance of identifying the valuable customers a company has (Dong et al., 2021; Benoit and Van den Poel, 2009; Cooper and Kaplan, 1991). According to the Pareto Principle (also known as the $80 / 20$ rule), attributed to the Italian economist Vilfredo Pareto in $1897,80 \%$ of the results/output are generated by $20 \%$ of the effort/input (Wang et al., 2020; Koch, 2007). Transposing this idea in the area of customer relationship 
management, a percentage of $20 \%$ of customers is expected to generate $80 \%$ of revenue. Even more, new research suggests that the revenue generated by valuable customers exceeds by far $80 \%$ (Morisada et al., 2019; Cooper and Kaplan, 1991).

According to a statement attributed to Peter Drucker, if you want to manage something, you have to measure it. It should be the same when it comes to the value of a customer. Not only customer lifetime value is an essential marketing measure, but some studies show the link between CLV and the improved financial performance of a company (Gupta and Zeithaml, 2006; Hyun, 2009). As a result, CLV is considered a fundamental metric in modern marketing, in general, and Customer Relationship Management (CRM) in particular, as it helps companies identify the valuable customers. CLV thus becomes a key segmentation criterion for companies as part of their strategic approach to the market. On the other side, although the assessment of customer value has been greatly facilitated by information technology and the abundance of customer data (Matsuoka, 2020; Estrella-Ramón et al., 2013), the literature highlights the difficulty in calculating CLV, indicating the idea that it is perceived differently across industries (Mosaddegh et al., 2021; Binh et al., 2021).

The first idea of the concept seems to have been suggested by Kotler in 1974, however the concept began to gain real interest in the context of marketing theory in the 1990s (Matsuoka, 2020).

The literature covers a significant number of domains that tend to manifest great importance towards understanding and measuring the CLV: banking / financial services (Armelini et al., 2015; Estrella-Ramón et al., 2017; Donkers et al., 2007; Méndez-Suárez and Crespo-Tejero, 2021), fashion (Kim et al., 2012; Dahana et al., 2019), telecommunication (Binh et al., 2021; Dandis et al., 2021), airline business (Çavdar and Ferhatosmanoğlu, 2018), online shopping (Jasek et al., 2019), insurance (Farzanfar and Delafrooz, 2016), health (Khajvand et al., 2011; Tarokh and EsmaeiliGookeh, 2019), tourism and hospitality (Kim et al., 2018; Hyun, 2009).

In opening the discussion on the inflectional forms of the definitions given to the lifetime value of the client, it is required to mention the acronym paradigms used in its specialty literature from CLV or CLTV (customer lifetime value) to LCV (lifetime customer value) or LVT (lifetime value), we will establish as CLV positioning term.

The concept is defined as "the present value of all future profits obtained from a customer over the life of his relationship with a firm" by Gupta and Zeithaml (2006) or as "the present value of the future cash flows attributed to the customer relationship" by Pfeifer, Haskins and Conroy (2005). More general, CLV is "the present value of a customer's future benefits to a firm" (Zhang, 2016). So, the present estimation of CLV is related to what we predict the customer will do in the future.

Literature also mentions a significant number of benefits associated with CLV measurement: customer segmentation / help in the process of selection of profitable customers, using CLV in marketing decisions positively influences the financial performance of the company, improves the ability to allocate the marketing resources (Gupta and Zeithaml, 2006; Kumar et al., 2006).

Also, as a root to all these benefits, it is worth to be mentioned the possibility to identify the profile of the valuable customer based on CLV estimation and use it as 
the template for targeting prospects with an increased potential to become valuable customers.

\section{Research methodology}

To achieve the purpose of this study, an exploratory research was conducted. We approached qualitative data analysis based on content analysis. We investigated a number of 130 scientific articles published between 2000 and 2021 and selected from academic databases. The selected articles were the ones that had the keywords "Customer Lifetime Value" in the title, abstract or author-specified keywords. Content analysis was performed using the QDA Miner / WordStat application set (Provalis Research).

\section{Data analysis and results}

At this stage of the study that aims to investigate the interest on the subject of Customer Lifetime Value in the academic literature, we established the following topics of interest: the association with the Pareto principle (the 80/20 rule), the identification of the main themes and of the industries / domains with which CLV is most associated in the academic literature.

The analysis started by investigating the distribution of phrases with the highest incidence in the investigated articles (Figure 1). According to the results, we can see that general concepts such as "customer-centricity" or "customer segmentation" appear only in about half of the investigated articles. We expected these topics to be of higher incidence. On the other hand, "customer retention", "customer loyalty", "customer profitability / profitable customers / valuable customers" and "customer satisfaction" appear in about $70 \%$ of the articles.

As domains / areas to which the concept of Customer Lifetime Value is associated in the case studies of the articles we noticed that the "financial services / banking" is the most approached, but also "luxury brand" appear in the results even if with a much lower frequency. "Behavioral loyalty" and "Attitudinal loyalty" as dimensions of customer loyalty are also mentioned in the results. As calculation methods, our results indicate that the ones with the highest frequencies are those related to the Markov chain model, regression models, RFM model, Pareto NBD. 


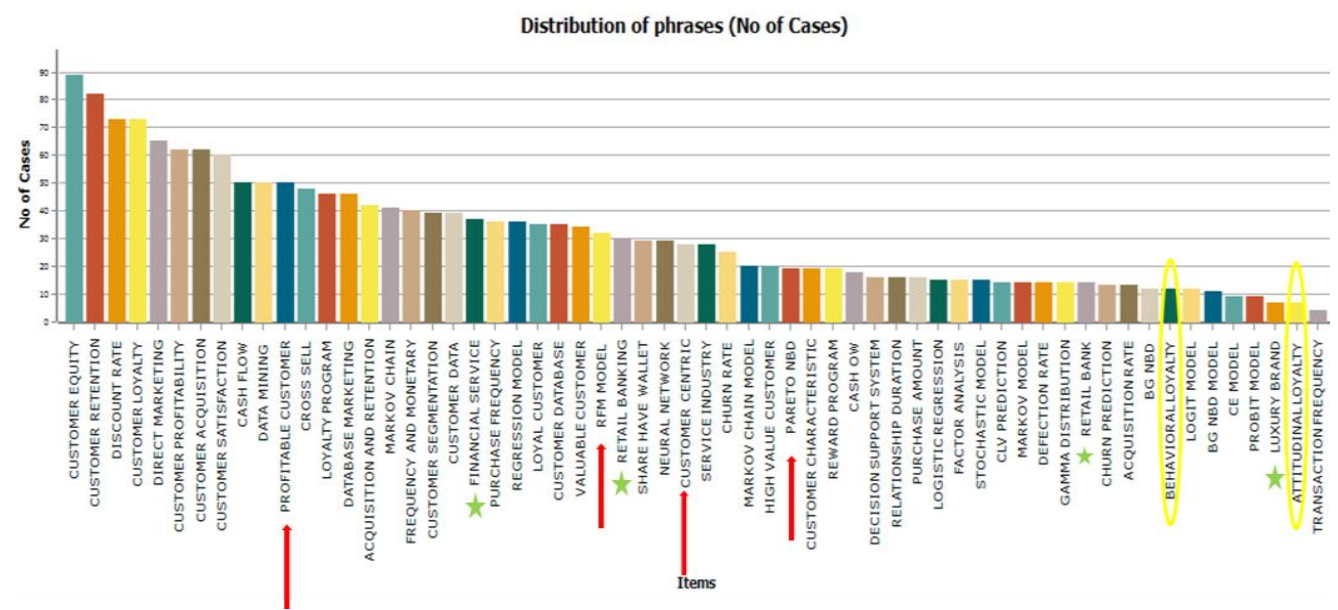

Figure 1: Distribution of phrases with the highest frequencies

Source: authors' own representation

The previous results are also reflected by the analysis of the general topics behind the keywords of these articles (Figure 2). According to our research, the topic of "customer satisfaction" (including also loyalty and customer profitability) and the calculation models are the topics most addressed in the articles analyzed.

\begin{tabular}{|c|c|c|c|c|c|c|c|}
\hline No & TOPIC & KEYWORDS & COHERENCE & EIGENVALUE & FREQ & CASES & $\%$ CASES \\
\hline 1 & CUSTOMER SATISFACTION & $\begin{array}{l}\text { BRAND; SATISFACTION; LOYALTY; RELATIONSHIP; ROLE; } \\
\text { INFLUENCE; CUSTOMER; CONSUMER; } \\
\text { CUSTOMER EQUITY; CUSTOMER SATISFACTION; CUSTOMER } \\
\text { LOYALTY; CUSTOMER PROFITABILITY; CUSTOMER } \\
\text { RELATIONSHIPS; }\end{array}$ & 0,358 & 5,30 & 9103 & 129 & $99,23 \%$ \\
\hline 2 & PROPOSED MODEL & $\begin{array}{l}\text { MODEL; DATA; SECTION; METHOD; PREDICTION; PROPOSE; } \\
\text { APPROACH; REGRESSION; RESULT; PRESENT; } \\
\text { PROPOSED MODEL; }\end{array}$ & 0,354 & 2,27 & 7495 & 129 & $99,23 \%$ \\
\hline 3 & CASH FLOW & $\begin{array}{l}\text { CASH; FLOW; } \\
\text { CASH FLOW; CASH FLOWS; DISCOUNTED CASH FLOW; FUTURE } \\
\text { CASH FLOWS; }\end{array}$ & 0,272 & 2,08 & 1049 & 61 & $46,92 \%$ \\
\hline 4 & $\begin{array}{l}\text { FREQUENCY AND MONETARY } \\
\text { RECENCY }\end{array}$ & $\begin{array}{l}\text { RECENCY; MONETARY; FREQUENCY; RFM; } \\
\text { FREQUENCY AND MONETARY; PURCHASE FREQUENCY; RFM } \\
\text { MODEL; PURCHASE FREQUENCY AND MONETARY; } \\
\text { TRANSACTION FREQUENCY; RFM VARIABLES; WEIGHTED RFM; }\end{array}$ & 0,374 & 2,04 & 1460 & 93 & $71,54 \%$ \\
\hline 5 & $\begin{array}{l}\text { CUSTOMER RETENTION } \\
\text { ACQUISIMION }\end{array}$ & $\begin{array}{l}\text { ACQUISITION; RETENTION; RESOURCE; ALLOCATE; FIRM; } \\
\text { ACQUIRE; CUSTOMER; } \\
\text { CUSTOMER RETENTION; CUSTOMER ACQUISITION; CUSTOMER } \\
\text { EQUIT; ACQUSITION AND RETENTION; CUSTOMER } \\
\text { PROFITABIITY; CUSTOMER SATISFACTION; CUSTOMER } \\
\text { RELATIONSHIPS; }\end{array}$ & 0,379 & 1,69 & 8024 & 128 & $98,46 \%$ \\
\hline 6 & RETAIL BANKING & $\begin{array}{l}\text { BANKING; RETAIL; BANK; INDUSTRY; } \\
\text { RETAIL BANKING; BANKING INDUSTRY; RETAIL BANK; RETAIL } \\
\text { BANKING CONTEXT; TARGET BANK; MODEL TO DETERMINE } \\
\text { CUSTOMER LIFETIME; BANKKING SECTOR; RETAIL BANKING } \\
\text { INDUSTRY; DETERMINE CUSTOMER; }\end{array}$ & 0,317 & 1,66 & 1193 & 105 & $80,77 \%$ \\
\hline 7 & $\begin{array}{l}\text { LOW CLV } \\
\text { NEGATIVE }\end{array}$ & $\begin{array}{l}\text { NEGATIVE; HIGH; POSITIVE; LOW; DECREASE; INCREASE; } \\
\text { LOW CLV; CLV CUSTOMERS; HIGH CLV CUSTOMERS; POSITIVE } \\
\text { IMPACT; }\end{array}$ & 0,346 & 1,62 & 1812 & 126 & $96,92 \%$ \\
\hline 8 & $\begin{array}{l}\text { RECOMMENDATION RULES } \\
\text { QUALTY }\end{array}$ & $\begin{array}{l}\text { RECOMMENDATION; QUALITY; PREFERENCE; ITEM; } \\
\text { RECOMMENDATION RULES; RECOMMENDATION QUALITY; } \\
\text { IMPROVE THE QUALITY; EXTRACT RECOMMENDATION RULES; } \\
\text { QUALITY OF RECOMMENDATION; BASED RECOMMENDATION; } \\
\text { PROPOSED HYBRID; ; ASED METHOD; PURCHASE PREFERENCE; } \\
\text { ASSOCIATION RULE MINING; CANDIDATE PRODUCTS; QUALITY } \\
\text { OF RECOMMENDATTONS; RECOMMENDATION RULE SET; CF } \\
\text { METHOD; BASED CF METHOD; }\end{array}$ & 0,317 & 1,56 & 607 & 78 & $60,00 \%$ \\
\hline 9 & $\begin{array}{l}\text { RECEIVE SPECIAL TREATMENT } \\
\text { REVISE }\end{array}$ & $\begin{array}{l}\text { REVISE; ACCEPT; RECEIVE; FORM; } \\
\text { RECEIVE SPECIAL TREATMENT; SPECIAL TREATMENT; }\end{array}$ & 0,291 & 1,52 & 505 & 114 & $87,69 \%$ \\
\hline 10 & CROSS BUYING & $\begin{array}{l}\text { SELL; CROSS; } \\
\text { CROSS BUYING; }\end{array}$ & 0,296 & 1,46 & 808 & 83 & $63,85 \%$ \\
\hline 11 & DISCOUNT RATE & $\begin{array}{l}\text { RATE; DISCOUNT; ASSUME; TIME; PERIOD; CONSTANT; } \\
\text { ASSUMPTION; PROBABILITY; PURCHASE; } \\
\text { DISCOUNT RATE; }\end{array}$ & 0,363 & 1,43 & 4015 & 128 & $98,46 \%$ \\
\hline 12 & $\begin{array}{l}\text { DATA MINING } \\
\text { AMOUNT }\end{array}$ & $\begin{array}{l}\text { DATA; AMOUNT; INFORMATION; } \\
\text { DATA MINING; CUSTOMER DATA; DATA SETS; }\end{array}$ & 0,283 & 1,39 & 1429 & 126 & $96,92 \%$ \\
\hline
\end{tabular}

Figure 2: The general topics behind the keywords of the investigated articles Source: authors' own representation 


\section{Conclusion}

The importance of understanding the concept of Customer Lifetime Value is of increasing interest in the academic literature, as reflected in the number of papers included in scientific databases in recent years. The dynamics of information technology and the possibility to collect in-depth information about customers will accelerate the interest in finding new ways to assess the lifetime value of customers and use it to develop specific marketing strategies focused on valuable customers.

As expected, concepts like "customer retention", "customer loyalty", "customer profitability / profitable customers / valuable customers", and "customer satisfaction" were frequently mentioned among the investigated articles. But, on the other hand, concepts like "customer-centricity" or "customer segmentation", and the correlation with the Pareto principle (the 80/20 rule) had lower frequencies than we expected.

According to the results of our study, banking / financial services is the most approached domain in the case studies of the articles related to the topic "customer lifetime value".

Perhaps it is time to reconsider the statement that customers are a organization's most valuable asset to the idea that valuable customers are the organization's genuinely most valuable asset. The academic literature also provides a significant number of reasons why CLV should be considered an important segmentation criterion for developing a companies' marketing strategy.

As further research directions, we intend to continue the study by investigating articles written by practitioners to compare the ways in which the concept is approached by both academics and company practitioners.

\section{References}

1. Armelini, G., Barrot, C. and Becker, J. U. (2015). 'Referral programs, customer value, and the relevance of dyadic characteristics', International Journal of Research in Marketing, 32(4), pp. 449-452.

2. Benoit D. and Van den Poel, D. (2009). 'Benefits of quantile regression for the analysis of customer lifetime value in a contractual setting: An application in financial services', Expert Systems with Applications, 36(7), pp.10475-10484.

3. Binh, T. V., Thy, N. G. and Phuong, H. T. N. (2021). 'Measure of CLV Toward Market Segmentation Approach in the Telecommunication Sector (Vietnam)', SAGE Open, 11(2).

4. Çavdar, A. B. and Ferhatosmanoğlu, N. (2018). 'Airline customer lifetime value estimation using data analytics supported by social network information', Journal of Air Transport Management, vol. 67, pp. 19-33.

5. Cooper, R. and Kaplan, R.S. (1991). 'Profit priorities from activity-based costing'. Harvard Business Rev., 69 (3), pp.130-135.

6. Dahana, W. D., Miwa, Y. and Morisada, M. (2019). 'Linking lifestyle to customer lifetime value: An exploratory study in an online fashion retail market', Journal of Business Research, Volume 99, pp. 319-331.

7. Dandis, A. O., Al Haj Eid, M. B., Robin, R. and Wierdak, N. (2021). 'An empirical investigation of the factors affecting customer lifetime value', International Journal 
of Quality and Reliability Management, ahead-of-print. 10.1108/IJQRM-12-20200412.

8. Dong, Y., Li, C.and $\mathrm{Li}, \mathrm{H}$. (2021). 'Customer concentration and M\&A performance', Journal of Corporate Finance, Volume 69, 102021.

9. Donkers, B., Verhoef, P. C. and de Jong, M. G. (2007). 'Modeling CLV: A test of competing models in the insurance industry', Quantitative Marketing and Economics, 5(2), pp. 163-190.

10. Estrella-Ramón, A., Sánchez-Pérez, M., Swinnen, G. and Vanhoof, K. (2013). 'A marketing view of customer value: Customer lifetime value and customer equity', South African Journal of Business Management, 44, pp. 47-64.

11. Estrella-Ramón, A., Sánchez-Pérez, M., Swinnen, G. and VanHoof, K. (2017). 'A model to improve management of banking customers', Industrial Management and Data Systems, 117(2), pp. 250-266.

12. Farzanfar, E. and Delafrooz, N. (2016). 'Determining the customer lifetime value based on the benefit clustering in the insurance industry'. Indian Journal of Science and Technology, 9(1).

13. Gupta, S. and Zeithaml, V. (2006). 'Customer Metrics and Their Impact on Financial Performance', Special 25th Anniversary Issue. Marketing Science, 25(6), pp.718-739.

14. Hyun, S. S. (2009). 'Creating a model of customer equity for chain restaurant brand formation', International Journal of Hospitality Management - INT J HOSP MANAG., Volume 28, Issue 4, pp. 529-539.

15. Jasek, P., Vrana, L., Sperkova, L., Smutny, Z. and Kobulsky, M. (2019). 'Comparative analysis of selected probabilistic customer lifetime value models in online shopping', Journal of Business Economics and Management, 20(3), pp. 398-423.

16. Khajvand, M., Zolfaghar, K., Ashoori, S. and Alizadeh, S. (2011). 'Estimating customer lifetime value based on RFM analysis of customer purchase behavior: Case study', Paper presented at the Procedia Computer Science, 3, pp. 57-63.

17. Kim, K. H., Ko, E., Xu, B. and Han, Y. (2012). 'Increasing customer equity of luxury fashion brands through nurturing consumer attitude', Journal of Business Research, 65(10), pp. 1495-1499.

18. Kim, Y. P., Boo, S and Qu, H. (2018). 'Calculating tourists' customer equity and maximizing the hotel's ROI', Tourism Management, vol. 69, pp. 408-421.

19. Koch, R. (2007). The 80/20 Principle: The secret to achieving more with less, London: Nicholas Brealey Publishing.

20. Kumar, V., Lemon, K. N. and Parasuraman, A. (2006). 'Managing customers for value: An overview and research agenda', Journal of Service Research, 9(2), pp. 87-94.

21. Matsuoka, K. (2020). 'Exploring the interface between management accounting and marketing: a literature review of customer accounting', Journal of Management Control: Zeitschrift für Planung und Unternehmenssteuerung, Springer, vol. 31(3), pp. 157-208.

22. Méndez-Suárez, M. and Crespo-Tejero, N. (2021). 'Why do banks retain unprofitable customers? A customer lifetime value real options approach', Journal of Business Research, Volume 122, pp. 621-626.

23. Morisada, M., Miwa, Y. and Dahana, W. D. (2019). 'Identifying valuable customer segments in online fashion markets: An implication for customer tier programs', Electronic Commerce Research and Applications, Volume 33, 100822. 
24. Mosaddegh, A., Albadvi, A., Sepehri, M. M. and Teimourpour, B. (2021). 'Dynamics of customer segments: A predictor of customer lifetime value', Expert Systems with Applications, 172, 114606.

25. Pfeifer, P. E., Haskins, M. E. and Conroy, R. M. (2005). ' Customer Lifetime Value, Customer Profitability, and the Treatment of Acquisition Spending', Journal of Managerial Issues, 17(1), pp. 11-25.

26. Provalis Research (2019). -QDA Miner - qualitative data analysis softwarell, [Online], available at: www. provalisresearch.com.

27. Tarokh, M. J. and EsmaeiliGookeh, M. (2019). 'Modeling patient's value using a stochastic approach: An empirical study in the medical industry', Computer Methods and Programs in Biomedicine, Volume 176, pp. 51-59.

28. Wang, Y., Wang, B. and Huang, Y. (2020). 'Comprehensive analysis and mining big data on smart E-commerce user behavior', Paper presented at the Journal of Physics: Conference Series, 1616(1).

29. Zhang, S.T. (2016). 'Firm valuation from customer equity: When does it work and when does it fail?', International Journal of Research in Marketing, Volume 33, Issue 4, pp. 966-970. 